\title{
A Comparative Evaluation of Operational Efficiency of Wood Industry Using Data Envelopment Analysis and Malmquist Productivity Index: the Cases of Slovenia and Croatia
}

\section{Usporedna procjena operativne učinkovitosti drvne industrije Slovenije i Hrvatske primjenom analize omeđivanja podataka i Malmquistova indeksa produktivnosti}

\author{
Original scientific paper $\bullet$ Izvorni znanstveni rad \\ Received-prispjelo: 10. 6. 2019. \\ Accepted-prihvaćeno: 4. 7. 2019. \\ UDK: $630 * 79$ \\ https://doi.org/10.5552/drvind.2019.1937
}

\begin{abstract}
The wood industry, as a traditional sector, represents a very important part of the economy in terms of ensuring a sustainable development of society and transition to a low-carbon society in both countries studied, Slovenia and Croatia. For its further development, it is crucial to know the current position of the industry. The best way to achieve this is an analysis of financial data and international comparative evaluation of its operational efficiency. The aim of the research is to compare the relative efficiency of the wood industry using Data Envelopment Analysis (DEA) and the Malmquist Productivity Index (MI), focusing on the Slovenian and Croatian wood industry sectors (C16 and C31) for a recent five-year period (from 2013-2017). With this purpose, the combined measure DEA/MI was applied. The analysis includes only the highest rated companies with more than five employees, divided into 12 clusters regarding the company size. As a result, it was established that clusters CRO-C31micro, CRO-C16-micro and SI-C16-larger have the highest operational efficiency, due to the effects of different financial indicators, especially activity and liquidity ratios. In general, within the grouped clusters regarding country and subsector, groups SI-C16 and CRO-C31 achieve the highest values for the average of weighted score of efficiency, while CRO-C16 achieves the lowest values.
\end{abstract}

Keywords: financial analysis, financial ratio, wood industry, Slovenia, Croatia, DEA, Malmquist Index

\footnotetext{
${ }^{1}$ Authors are assistant professor and teaching assistant at University of Ljubljana, Biotechnical Faculty, Department of Wood Science and Technology, Ljubljana, Slovenia. ${ }^{2}$ The authors are a postdoctoral researcher, assistant professor and professor at University of Zagreb, Faculty of Forestry, Wood Technology Department, Zagreb, Republic of Croatia ${ }^{3}$ Author is assistant professor at University of Ljubljana, Biotechnical Faculty, Department of Forestry and Renewable Forest Resources, Ljubljana, Slovenia.

Autori su docent i asistent Sveučilišta u Ljubljani, Biotehnički fakultet, Zavod za znanost o drvu i tehnologiju, Ljubljana, Slovenija. ${ }^{2}$ Autori su postdoktorand, docent i profesor Sveučilišta u Zagrebu, Šumarski fakultet, Drvnotehnološki odsjek, Zagreb, Hrvatska. ${ }^{3}$ Autor je docent Sveučilišta u Ljubljani, Biotehnički fakultet, Zavod za šumarstvo i obnovljive šumske resurse, Ljubljana, Slovenija.
} 
SAŽETAK • Drvna industrija Sloveniji i Hrvatskoj tradicionalan je gospodarski sektor tih zemalja i vrlo važan dio gospodarstva u smislu osiguranja održivog razvoja društva i prijelaza na društvo s niskim udjelom ugljika. Za daljnji razvoj drvnoga sektora bitno je poznavati trenutačni položaj industrije, a najbolji način za to je analiza financijskih podataka i internacionalna usporedna procjena industrijske operativne učinkovitosti. Cilj istraživanja bio je usporediti relativnu učinkovitost drvne industrije uz pomoć analize omeđivanja podataka (DEA) i Malmquistova indeksa produktivnosti (MI), s naglaskom na slovenski i hrvatski drvnoindustrijski sektor (C16 I C 31) tijekom posljednjih pet godina (2013. - 2017.). Za tu je svrhu primijenjena kombinirana mjera DEA/MI. Analizom su obuhvaćene samo najbolje ocijenjene tvrtke s više od pet zaposlenih, koje su s obzirom na njihovu veličinu podijeljene na 12 klastera. Utvrđeno je da klasteri CRO-C31-mikro, CRO-C16-mikro i SI-C16-veliki zbog utjecaja različitih financijskih pokazatelja, posebice omjera aktivnosti i likvidnosti, imaju najveću operativnu učinkovitost. Općenito, unutar klastera grupiranih prema zemlji i podsektoru istraživanja, skupine SI-C16 i CRO-C31 pokazale su najviše vrijednosti za prosjek ponderirane ocjene učinkovitosti, a CRO-Cl6 imao je najniže vrijednosti.

Ključne riječi: financijska analiza, financijski omjer, drvna industrija, Slovenija, Hrvatska, DEA, Malmquistov indeks

\section{INTRODUCTION}

\section{UVOD}

The wood industry, as a traditional sector, represents a very important part of the economy in terms of ensuring a sustainable development of society, enabling a circular economy and transition to a low-carbon society (Klarić et al., 2016; Perić et al., 2015; Perić et al., 2019; Šooš et al., 2017). The management of natural resources must be effective and sustainable, and on the other hand, it must provide growth and development for the economy, in order to make it even more successful. Financial analysis is often used in order to see the current condition of individual companies, sectors and countries, and this is an important tool for assessing the financial position and success of a company and/or sector, in terms of calculating fiscal indicators, while measuring current fiscal conditions and performance, and predicting trends (Friedlob and Schleifer, 2003; Helfert, 2001; Palepu et al., 2003; Vance, 2003).

However, knowing the fiscal position of a country is rather limited in terms of understanding the broader situation and trends, and it is also not enough to provide data and financial analysis for just one sector (Kropivšek and Grošelj, 2019; Potkány and Giertl, 2014), as only a comparative analysis using data from companies in different sectors and different countries can provide comprehensive information. There is little information with regard to international comparative financial analysis of the wood sector in the literature, and there is no such analysis for Slovenia and Croatia. The wood-industry sector in Slovenia and Croatia has already been analysed financially (Kropivšek et al., 2017, 2011; Kropivšek and Jošt, 2013; Pirc Barčić et al., 2015; Tratnik et al., 2001), but such analysis has been done separately for each country. In addition, an international comparative evaluation of the operational efficiency of the wood-industry sector has never been done. This comparison would be very interesting, as Slovenia has a long tradition in the wood sector with a relatively stable economic situation, while Croatia has experienced significant economic growth in recent years (CBS, 2019).
So, the aim of the current research is to use Data Envelopment Analysis (DEA) and the Malmquist Productivity Index (MI) to compare the relative efficiency of the Slovenian and Croatian wood industry sectors (C16 (manufacture of wood and of products of wood and cork, except furniture; manufacture of articles of straw and plaiting materials; in short: wood processing) and C31 (manufacture of furniture)) (Braunsberger et al., 2010) for a recent five-year period (from 2013-2017). With this purpose, the combined measure DEA/MI was applied. DEA/MI enables us to measure the productivity of decision-making units (DMUs), which is a combination of relative efficiency and the change in productivity between two time periods, and to rank the DMUs regarding their productivity. The analysis includes only the highest rated companies (with a grade A financial rating with regard to credit appraisal in 2017) and with more than five employees.

The DEA approach and MI are widely used for evaluating the efficiency and productivity changes of sectors in addition to the use of financial indicators (Bui et al., 2016; Fenyves et al., 2015; Fernández et al., 2018; Halkos and Tzeremes, 2012a, 2012b; Johnes et al., 2009; Li and Wu, 2016; Liu and Wang, 2008; Örkcü et al., 2016; Sueyoshi and Goto, 2013). The DEA method has also been applied several times in the wood industry. For example, Salehirad and Sowlati (2006) prepared a review of productivity and efficiency assessments of the wood industry in Canada. An analysis of productive efficiency has also been carried out for Spain's wood-based industry (Diaz-Balteiro et al., 2006), the Iranian wood panels industry (Hemmasi et al., 2011), Canadian wood-product manufacturing subsectors (Sowlati and Vahid, 2006) and Slovenian wood industry (Kropivšek and Grošelj, 2019). The MI has been used for evaluating the changes in productivity of manufacturing industries in Canada, with a focus on the wood manufacturing sector (Sowlati and Vahid, 2006) and on primary wood producers in British Columbia (Salehirad and Sowlati, 2007). The combined DEA/MI measure was also applied for evaluating police force efficiency (Hadad et al., 2015) and public forest services in Slovenia (Zadnik Stirn et al., 2015). 


\section{MATERIALS AND METHODS}

\section{MATERIJALI I METODE}

\subsection{Sample}

2.1. Uzorak

In calculating the indicators, the financial data for the highest rated companies and sole proprietors (with the grade $\mathrm{A}$ in the financial rating for the credit appraisal in 2017) and with more than five employees in 2017 operating in sub-sectors C16 (wood processing) and C31 (manufacture of furniture) in Slovenia and Croatia were considered, according to the sub-sector level data in the classification of economic activities NACE (Nomenclature of Economic Activities) rev.2 classification (NACE, 2019). The research was based on searching and preparing data from official statistical databases (Ajpes JOLP, 2019; Analitika GZS, 2019; Bisnode, 2019) for the period from 2013 to 2017 (five years).

The sample size was based on the number of companies in both sectors as of $27^{\text {th }}$ February 2019 (Bisnode, 2019). The data show (Table 1) that the numbers of active companies in two sub-sectors separately are more or less similar in both countries; this also applies to the size proportion of C16 and C 31 sub-sectors. However, only $13 \%$ (in Slovenia) and $22 \%$ of companies in Croatia have more than 5 employees; majority of companies in both countries are very small with less than 5 employees. On average $3.1 \%$ and $4 \%$ of all active companies were rated with the grade A credit appraisal and these companies were than evaluated. On the other hand, almost $25 \%$ of companies in
Slovenia and $18.7 \%$ in Croatia with more than 5 employees were rated with the grade A credit appraisal.

In the next phase, these companies were grouped into clusters regarding the size of the company (according to: ZGD-1-UPB3, 2009). These clusters are: (1) micro, (2) small, (3) middle-sized and (4) large companies. Since a very small number of companies was established in the cluster of large companies $(>250$ employees) with the grade A credit appraisal for both countries and sectors (only one in Slovenia and two in Croatia), we decided to join that cluster and cluster of middle-sized companies into the cluster of larger companies (>50 employees). Consequently, three comparable clusters regarding the size were obtained (Table 2 ). The majority of companies (81\% in Croatia, and $91.6 \%$ in Slovenia) belong to clusters of micro and small companies, while the clusters of larger companies is rather small, especially in Slovenia (8.4\%).

\subsection{Data}

2.2. Podatci

For further analysis, the method of financial ratio analysis was used, where the resulting ratio is an expression of a mathematical relationship between two quantities (Peterson-Drake and Fabozzi, 2010). Data sources for financial analysis are the firm's financial statements, in which a large amount of data is reduced to a few key parameters (Gitman, 2003). The data for this research were obtained from official statistical databases (Bisnode, 2019) for the period from 2013 to 2017 (5 years), where data of all companies were gath-

Table 1 Sample size and structure of companies in the year 2017 (Bisnode, 27. 2. 2019.)

Tablica 1. Veličina uzorka i struktura tvrtki u 2017. (Bisnode, preuzeto 27. veljače 2019.)

\begin{tabular}{|c|c|c|c|c|c|c|}
\hline \multirow[b]{2}{*}{$\begin{array}{l}\text { Country } \\
\text { Država }\end{array}$} & \multirow[b]{2}{*}{$\begin{array}{l}\text { Sector } \\
\text { Sektor }\end{array}$} & \multirow[b]{2}{*}{$\begin{array}{c}\text { All active } \\
\text { companies } \\
\text { Sve aktivne tvrtke }\end{array}$} & \multicolumn{2}{|c|}{$\begin{array}{c}\text { Number of companies } \\
\text { Broj tvrtki }\end{array}$} & \multicolumn{2}{|c|}{$\begin{array}{c}\text { Share of grade A companies } \\
\text { Postotni udio tvrtki s bonitet- } \\
\text { nom ocjenom A }\end{array}$} \\
\hline & & & $\begin{array}{l}>\mathbf{5} \text { employees } \\
>5 \text { zaposlenih }\end{array}$ & $\begin{array}{c}\text { Grade } \mathbf{A}, \\
>\mathbf{5} \text { employees } \\
\text { Ocjena } A,>5 \text { zaposlenih }\end{array}$ & $\begin{array}{c}\text { All companies } \\
\text { Sve tvrtke }\end{array}$ & $\begin{array}{l}>5 \text { employees } \\
>5 \text { zaposlenih }\end{array}$ \\
\hline \multirow{3}{*}{$\begin{array}{l}\text { Slovenia } \\
\text { Slovenija }\end{array}$} & C 16 & 2212 & 250 & 63 & $2.8 \%$ & $25.2 \%$ \\
\hline & C 31 & 1189 & 180 & 44 & $3.7 \%$ & $24.4 \%$ \\
\hline & Total & 3401 & 430 & 107 & $3.1 \%$ & $24.9 \%$ \\
\hline \multirow{3}{*}{$\begin{array}{l}\text { Croatia } \\
\text { Hrvatska }\end{array}$} & C 16 & 2099 & 473 & 90 & $4.3 \%$ & $19.0 \%$ \\
\hline & C 31 & 1170 & 234 & 42 & $3.6 \%$ & $17.9 \%$ \\
\hline & Total & 3269 & 707 & 132 & $4.0 \%$ & $18.7 \%$ \\
\hline
\end{tabular}

Table 2 Classification of cluster companies with the grade A credit appraisal by number of employees in 2017 (Bisnode, 27. 2. 2019)

Tablica 2. Klasifikacija klasterskih tvrtki s bonitetnom ocjenom A prema broju zaposlenih za 2017. (Bisnode, preuzeto 27. veljače 2019.)

\begin{tabular}{|c|c|c|c|c|c|c|c|}
\hline & & \multicolumn{3}{|c|}{ Clusters / Klasteri, $\mathrm{n}$} & \multicolumn{3}{|c|}{ Clusters / Klasteri, \% } \\
\hline & $\begin{array}{l}\text { Cluster } \\
\text { Klaster }\end{array}$ & \multirow{2}{*}{$\begin{array}{l}\text { Micro: 5-9 } \\
\text { employees } \\
\text { Mikro: } 5-9 \\
\text { zaposlenih }\end{array}$} & \multirow{2}{*}{$\begin{array}{c}\text { Small: 10-49 } \\
\text { employees } \\
\text { Mala: } 10-49 \\
\text { zaposlenih }\end{array}$} & \multirow{2}{*}{$\begin{array}{c}\text { Large: }>\mathbf{5 0} \\
\text { employees } \\
\text { Velika: }>50 \\
\text { zaposlenih }\end{array}$} & \multirow{2}{*}{$\begin{array}{l}\text { Micro: 5-9 } \\
\text { employees } \\
\text { Mikro: } 5-9 \\
\text { zaposlenih }\end{array}$} & \multirow{2}{*}{$\begin{array}{c}\text { Small: 10-49 } \\
\text { employees } \\
\text { Mala: } 10-49 \\
\text { zaposlenih }\end{array}$} & \multirow{2}{*}{$\begin{array}{l}\text { Large: }>\mathbf{5 0} \\
\text { employees } \\
\text { Velika: }>50 \\
\text { zaposlenih }\end{array}$} \\
\hline $\begin{array}{c}\text { Country } \\
\text { Država }\end{array}$ & $\begin{array}{l}\text { Sector } \\
\text { Sektor }\end{array}$ & & & & & & \\
\hline \multirow{3}{*}{$\begin{array}{l}\text { Slovenia } \\
\text { Slovenija }\end{array}$} & C 16 & 25 & 31 & 7 & $39.7 \%$ & $49.2 \%$ & $11.1 \%$ \\
\hline & C 31 & 22 & 20 & 2 & $50.0 \%$ & $45.5 \%$ & $4.5 \%$ \\
\hline & Total & 47 & 51 & 9 & $43.9 \%$ & $47.7 \%$ & $8.4 \%$ \\
\hline \multirow{3}{*}{$\begin{array}{l}\text { Croatia } \\
\text { Hrvatska }\end{array}$} & C 16 & 20 & 54 & 16 & $22.2 \%$ & $60.0 \%$ & $17.8 \%$ \\
\hline & C 31 & 14 & 18 & 9 & $34.1 \%$ & $43.9 \%$ & $22.0 \%$ \\
\hline & Total & 34 & 72 & 25 & $26.0 \%$ & $55.0 \%$ & $19.0 \%$ \\
\hline
\end{tabular}


Table 3 A list of analysed financial indicators

Tablica 3. Pregled analiziranih financijskih pokazatelja

\begin{tabular}{|c|c|c|}
\hline \multicolumn{2}{|c|}{ Financial indicator / Financijski pokazatelj } & Classification / Klasifikacija \\
\hline $\mathrm{CR}$ & Current ratio / koeficijent tekuće likvidnosti & \multirow{3}{*}{$\begin{array}{l}\text { Liquidity ratio } \\
\text { omjer likvidnosti }\end{array}$} \\
\hline QR & Quick ratio / koeficijent ubrzane likvidnosti & \\
\hline CashR & Cash ratio / trenutačna likvidnost & \\
\hline ROE & Return on equity / stopa povrata kapitala & \multirow{3}{*}{$\begin{array}{l}\text { Profitability ratio } \\
\text { omjer profitabilnosti }\end{array}$} \\
\hline ROA & Return on assets / stopa povrata imovine & \\
\hline ROS & Return on sales / stopa povrata od prodaje & \\
\hline GVA & $\begin{array}{l}\text { Gross value added per employee ratio / omjer bruto dodane } \\
\text { vrijednosti po zaposleniku }\end{array}$ & \multirow{3}{*}{$\begin{array}{l}\text { Activity ratio } \\
\text { omjer aktivnosti }\end{array}$} \\
\hline ATR & Asset turnover ratio / omjer prometa imovine & \\
\hline CAT & Current asset turnover ratio / omjer obrtanja aktive & \\
\hline EBITDA & $\begin{array}{l}\text { Earnings before interest, taxes, depreciation, and amortization } \\
\text { dobit prije kamata, poreza, deprecijacije i amortizacije }\end{array}$ & \multirow{3}{*}{$\begin{array}{l}\text { Efficiency ratio } \\
\text { omjer učinkovitosti }\end{array}$} \\
\hline E & Total efficiency ratio / omjer ukupne učinkovitosti & \\
\hline $\mathrm{AU}$ & Asset utilization ratio / omjer iskorištenja imovine & \\
\hline $\mathrm{D} / \mathrm{E}$ & Debt to equity ratio / omjer duga $i$ kapitala & \multirow{3}{*}{$\begin{array}{l}\text { Leverage ratio } \\
\text { omjer financijske poluge }\end{array}$} \\
\hline TDA & Total debt to total assets ratio / omjer ukupnog duga & \\
\hline TLTSF & $\begin{array}{l}\text { Total liabilities to total sources of funds ratio / omjer ukupnih } \\
\text { obveza prema svim izvorima sredstava }\end{array}$ & \\
\hline
\end{tabular}

ered and calculated in aggregate form within each cluster separately for both countries.

The right selection of financial ratios and/or indicators is of key importance for the financial analysis; it has to be adapted to the intended use. There are many different financial indicators, which are classified into different groups, taking into account the content of indicators (Delen et al., 2013; Gombola and Ketz, 1983; Pirc Barčić et al., 2015; Sayari and Simga-Mugan, 2017). Kropivšek and Grošelj (2019) divided financial indicators into five categories: (1) liquidity ratios (which provide information on a firm's ability to meet its shortterm obligations), (2) profitability ratios (providing information on how well the company is managing its expenses), (3) activity ratios (with information on a firm's ability to manage its resources efficiently), (4) leverage ratios (including information on the degree of a firm's fixed financing obligations and its ability to meet them), and (5) efficiency ratios (indicating a firm's operating efficiency and explaining its business results in relation to various investments that have been made in the business process). This classification was also used within this research, where all 15 indicators from that study were analysed for further and detailed analysis (Table 3). Beside these indicators, Assets (A), Capital (C) and Number of Employees (NE) were also analysed.

\subsection{DEA analysis and Malmquist Productivity Index}

\subsection{DEA analiza i Malmquistov indeks produktivnosti}

DEA is a linear programming technique for evaluating the efficiency of decision-making units (DMUs) under multiple inputs and outputs. The technique creates a frontier set by efficient DMUs and compares it with inefficient DMUs to produce relative efficiency scores that are restricted to 1 . It was first proposed by
Charnes et al. (1978) as the CCR model, named after the authors Charnes, Cooper and Rhodes. Besides CCR with constant returns to scale, the $\mathrm{BCC}$ model, named after the authors Banker, Charnes and Cooper (Banker et al., 1984), with variable returns to scale, is one of the most popular models. Both models can be input oriented, aiming to minimize the level of inputs, while maintaining the current level of outputs, or output oriented, aiming to maximize the level of outputs, while maintaining the current level of inputs.

When using ratios, the DEA formulation with variable returns to scale (BCC model) should be used (Ablanedo-Rosas et al., 2010; Hollingsworth and Smith, 2003). To include negative data in the DEA models, the appropriate translation that assures positive values should be performed (Pastor and Ruiz, 2007). This was the case with the profitability ratios ROA, ROE and ROS in the current study. To include the data where greater values are undesirable in the DEA models, the data should be multiplied by factor $(-1)$, followed by an appropriate translation to gain positive values (Seiford and Zhu, 2002). This was the case with the leverage ratios D/E, TDA and TLTSF. If a translation of the data is undertaken, it is important to ensure that the results of a model do not change from what they would be under the original data (Cook and Seiford, 2009). Considering BCC models, the BCC output oriented model is translation invariant in inputs, while the BCC input oriented model is translation invariant in outputs (Cooper et al., 2006). We selected the latter model to get ratios as outputs.

We considered $\mathrm{N}$ decision units (DMUs), $\mathrm{n}=1, \ldots, \mathrm{N}$ to be evaluated on the basis of $r$ inputs and $s$ outputs. The input-oriented DEA BCC model (in envelopment form) with variable returns to scale (VRS) is formulated by the following linear programs: 


$$
\begin{aligned}
& \min E_{i}-\varepsilon\left(\sum_{j=1}^{r} s_{j}^{-}+\sum_{k=1}^{s} s_{k}^{+}\right) \\
& \text {subject to } \sum_{n=1}^{N} \lambda_{n} x_{j n}+s_{j}^{-}=E_{i} x_{j i}, j=1, \ldots, r \\
& \sum_{n=1}^{N} \lambda_{n} y_{k n}+s_{k}^{+}=y_{k i}, \mathrm{k}=1, \ldots, \mathrm{s} \\
& \sum_{n=1}^{N} \lambda_{n}=1 \\
& \lambda_{n}, s_{j}^{-}, s_{k}^{+} \geq 0, n=1, \ldots, N, j=1, \ldots, r, \mathrm{k}=1, \ldots, \mathrm{s}
\end{aligned}
$$

$E_{i}$ unconstrained

where $E_{i}$ is the relative efficiency of assessed DMU $i, \varepsilon$ is a non-Archimedean infinitesimal value designed to enforce strict positivity on the variables, $x_{j n}$ is the amount of input $j$ used by DMU $n, y_{k n}$ is the amount of output $k$ produced by DMU $n, s_{j}^{-}$and $s_{j}^{+}$are vectors of slack variables and $\lambda_{n}$ are linear weights.

The Malmquist Productivity Index MI was developed by Färe et al. (1994) to measure the total productivity changes between time periods $t$ (base period) and $t+1$

$M I\left(x^{t}, \mathrm{y}^{t}, x^{t+1}, \mathrm{y}^{t+1}\right)=\left[\frac{D^{t}\left(x^{t+1}, \mathrm{y}^{t+1}\right)}{D^{t}\left(x^{t}, \mathrm{y}^{t}\right)} \times \frac{D^{t+1}\left(x^{t+1}, \mathrm{y}^{t+1}\right)}{D^{t+1}\left(x^{t}, \mathrm{y}^{t}\right)}\right]^{1 / 2}$

where $y$ represents the output vector that can be produced by the input vector $x . D^{t}\left(x^{\mathrm{t}}, y^{t}\right)$ is defined as the output distance function. DMU's total productivity improves if $M I>1$, remains unchanged for $M I=1$ and declines for $M I<1$.

The combined DEA/MI score is calculated to rank the DMUs (Hadad et al., 2015; Zadnik Stirn et al., 2015). First, we calculate the average efficiency $\bar{E}_{i}$ of DMU $i$ as the arithmetic mean of the relative efficiencies of DMU $i$ over $T$ time periods

$$
\bar{E}_{i}=\frac{1}{T} \sum_{t=1}^{T} E_{i, \mathrm{t}},
$$

where $E_{i, t}$ is a relative efficiency of DMU $i$ in time period $t$ derived by the VRS model. Then we calculate the average Malmquist productivity index $\overline{M I}_{i}$ of DMU $i$ as the geometric mean of MI of DMU $i$ over $T$ time periods. As MI can be greater than 1, the average MI should be normalized:

$$
\begin{aligned}
\overline{M I}_{i}= & \left(M I_{i, 1,2} \times M I_{i, 2,3} \times \ldots \times M I_{i, \mathrm{~T}-1, \mathrm{~T}}\right)^{1 /(\mathrm{T}-1)} / \\
& / \max _{i=1, . ., N}\left(M I_{i, 1,2} \times M I_{i, 2,3} \times \ldots \times M I_{i, \mathrm{~T}-1, \mathrm{~T}}\right)^{1 /(\mathrm{T}-1)},
\end{aligned}
$$

where $M I_{i, \mathrm{t}-1, \mathrm{t}}$ is a MI of DMU $i$ over time periods $t$ and $t+1$ derived by model. The DEA/MI score for each model $j=1, \ldots, M$ is the weighted sum of the average efficiency and the normalized average of MI:

$$
D E A / M I_{i}(j)=w_{1} \bar{E}_{i}+w_{2} \overline{M I}_{i}, i=1, \ldots, N, j=1, \ldots, M,
$$

where $w_{1}$ and $w_{2}$ are the weights of importance of the DEA and MI parts, respectively, with $w_{1}+w_{2}=1$. The final $D E A / M I_{i}$ score is the weighted sum of $D E A$ / $M I_{i}(j)$ scores over all the models $j=1, \ldots, M$ :

$$
D E A / M I_{i}=\sum_{j=1}^{M} u_{j} D E A / M I_{i}(j),
$$

where $u_{j}, j=1, \ldots, M$ are the weights of importance of the DEA/MI models, with $\sum_{j=1}^{M} u_{j}=1$.

Different models have been created for detailed analysis of the efficiency of sub-sectors in both countries. Based on many studies (Bui et al., 2016; Fenyves et al., 2015; Halkos and Tzeremes, 2012a, 2012b; Li and $\mathrm{Wu}, 2016$; Nikoomaram et al., 2010; Oberholzer and Westhuizen, 2004), where financial ratios have been used for DEA models, we formed our models using different ratios.

Five DEA models were considered with selected groups of ratios as outputs. Liquidity ratios were the outputs for Model 1, profitability ratios for Model 2, activity ratios for Model 3, efficiency ratios for Model 4 and leverage ratios for Model 5 (Table 3). Non-ratio data (Assets (A), Capital (C) and Number of Employees (NE)) were used as inputs for all models.

For all inputs and outputs of Models 1-5, the time series within the period from 2013 to 2017 were analysed using IBM SPSS Statistics V25. One-way ANOVA was used to test the differences in input and output values between two sub-sectors and between Slovenia and Croatia. The Kolmogorov-Smirnov test was performed to check the normality of the data and Levene's test was performed to check the differences between the variances of the groups. Post-hoc tests were used to detect the differences between pairs of compared groups, Bonferroni's procedure when the data variances were similar and Games-Howell procedure in case of doubt about the equality of data variances.

\section{RESULTS AND DISCUSSION} 3. REZULTATI I RASPRAVA

\subsection{Descriptive statistics and post-hoc tests} 3.1. Deskriptivna statistika i post-hoc testovi

The descriptive statistics of inputs and outputs of Models 1-5 for the year 2017 are presented in Table 4. The sample for calculating descriptive statistics includes companies with the grade A financial rating for their credit appraisal and with more than five employees in 2017. It is shown that there were statistically significant differences between the values of variables $\mathrm{A}$, $\mathrm{C}$, NE and EBITDA among the observed companies, which was expected as the sample includes micro, small and larger companies. It is interesting, however, that the values of most other indicators are very different, although only companies with a credit appraisal rating $\mathrm{A}$ with at least five employees were taken into account. It can be established that, on average, all companies showed excellent solvency (liquidity) and profitability ratios, with a very low share of debts, which shows their excellence.

We tested the differences between the values of indicators for Slovenia (SI) and Croatia (CRO) and sectors $\mathrm{C} 16$ and $\mathrm{C} 31$. The differences between the four groups were statistically significant for the majority of the indicators. Although the comparison also shows that the average values of the indicators are quite simi- 
Table 4 Descriptive statistics of inputs and outputs in Models 1-5 for the year 2017

Tablica 4. Deskriptivna statistika ulaza i izlaza u modelima 1. - 5. za 2017.

\begin{tabular}{|c|c|c|c|c|c|c|}
\hline $\begin{array}{l}\text { Model } \\
\text { Model }\end{array}$ & $\begin{array}{l}\text { Group } \\
\text { Skupina }\end{array}$ & $\begin{array}{c}\text { Financial } \\
\text { indicator } \\
\text { Financijski } \\
\text { pokazatelj }\end{array}$ & $\begin{array}{c}\text { Mean } \\
\text { Srednja } \\
\text { vrijednost }\end{array}$ & $\begin{array}{c}\text { Min } \\
\text { Minimum }\end{array}$ & $\begin{array}{c}\text { Max } \\
\text { Maksimum }\end{array}$ & $\begin{array}{l}\text { Std. Dev. } \\
\text { Standardna } \\
\text { devijacija }\end{array}$ \\
\hline \multirow{3}{*}{$\begin{array}{l}\text { Input for Model 1-5 } \\
\text { ulazi za modele } 1 . \\
-5 \text {. }\end{array}$} & Assets / imovina & $\mathrm{A}$ & $2,725,001 €$ & $22,922 €$ & $65,155,475 €$ & $6,706,358 €$ \\
\hline & Capital / kapital & $\mathrm{C}$ & $1,837,445 €$ & $17,667 €$ & $57,413,853 €$ & $5,331,940 €$ \\
\hline & $\begin{array}{l}\text { Number of employees } \\
\text { broj zaposlenih }\end{array}$ & $\mathrm{NE}$ & 36.2 & 5.0 & 458.0 & 64.7 \\
\hline \multirow{3}{*}{$\begin{array}{l}\text { Output for Model } 1 \\
\text { izlazi za model } 1 .\end{array}$} & \multirow{3}{*}{$\begin{array}{l}\text { Liquidity ratio } \\
\text { omjer likvidnosti }\end{array}$} & $\mathrm{CR}$ & 3.430 & 0.377 & 21.070 & 3.158 \\
\hline & & QR & 2.584 & 0.163 & 18.464 & 2.687 \\
\hline & & CashR & 1.493 & 0.000 & 16.877 & 2.302 \\
\hline \multirow{3}{*}{$\begin{array}{l}\text { Output for Model } 2 \\
\text { izlazi za model } 2 .\end{array}$} & \multirow{3}{*}{$\begin{array}{l}\text { Profitability ratio } \\
\text { omjer profitabilnosti }\end{array}$} & ROA & $13.3 \%$ & $0.0 \%$ & $83.3 \%$ & $12.2 \%$ \\
\hline & & ROE & $23.6 \%$ & $0.0 \%$ & $166.9 \%$ & $22.5 \%$ \\
\hline & & ROS & $8.7 \%$ & $0.0 \%$ & $46.8 \%$ & $7.2 \%$ \\
\hline \multirow{3}{*}{$\begin{array}{l}\text { Output for Model } 3 \\
\text { izlazi za model } 3 .\end{array}$} & \multirow{3}{*}{$\begin{array}{l}\text { Activity ratio } \\
\text { omjer aktivnosti }\end{array}$} & GVA & $34,157 €$ & $5,957 €$ & $451,464 €$ & $32,817 €$ \\
\hline & & ATR & 1.742 & 0.453 & 11.547 & 1.133 \\
\hline & & CAT & 3.433 & 0.603 & 24.945 & 2.587 \\
\hline \multirow{3}{*}{$\begin{array}{l}\text { Output for Model } 4 \\
\text { izlazi za model } 4 .\end{array}$} & \multirow{3}{*}{$\begin{array}{l}\text { Efficiency ratio } \\
\text { omjer učinkovitosti }\end{array}$} & EBITDA & $552,149 €$ & $154 €$ & $14,349,918 €$ & $1,475,460 €$ \\
\hline & & $\mathrm{E}$ & 1.132 & 1.003 & 2.291 & 0.133 \\
\hline & & $\mathrm{AU}$ & 1.738 & 0.454 & 9.474 & 1.063 \\
\hline \multirow{3}{*}{$\begin{array}{l}\text { Output for Model } 5 \\
\text { izlazi za model } 5 .\end{array}$} & \multirow{3}{*}{$\begin{array}{l}\text { Leverage ratio } \\
\text { omjer financijske poluge }\end{array}$} & $\mathrm{D} / \mathrm{E}$ & 0.753 & 0.032 & 5.492 & 0.769 \\
\hline & & TDA & 0.118 & 0.000 & 0.593 & 0.134 \\
\hline & & TLTSF & 0.329 & 0.026 & 0.846 & 0.185 \\
\hline
\end{tabular}

lar (Table 5), the objective of this paper is to focus on some more interesting results. Table 5 shows that the biggest differences can be observed in variables $\mathrm{A}$ (one-way ANOVA, F(3.16)=56.109, $\mathrm{p}<0.001$ ) and $\mathrm{C}$ (one-way ANOVA, F(3.16)=26.294, $\mathrm{p}<0.001$ ), where the values in SI-C16 are above average and SI-C31 below average, while those in CRO-C16 and CRO-C31 are average. Moreover, the variances of the groups differ for the variables A (Levene's test, $\mathrm{F}(3.16)=3.423$, $\mathrm{p}=0.043$ ) and $\mathrm{C}$ (Levene's test, $\mathrm{F}(3.16)=3.822$,

Table 5 Average values of inputs and outputs in Models 1-5 for 2017, for groups of financial indicators by country and subsector

Tablica 5. Prosječne vrijednosti ulaza i izlaza u modelima 1. - 5. za skupine financijskih pokazatelja po državama i podsektorima u 2017.

\begin{tabular}{|c|c|c|c|c|c|c|c|}
\hline \multicolumn{3}{|c|}{ Country / Država } & \multirow{2}{*}{$\begin{array}{l}\mathrm{SI}+\mathrm{CRO} \\
\mathrm{C} 16+\mathrm{C} 31\end{array}$} & \multirow{2}{*}{$\begin{array}{c}\text { SI } \\
\text { C16 }\end{array}$} & \multirow{2}{*}{$\begin{array}{l}\text { SI } \\
\text { C31 }\end{array}$} & \multirow{2}{*}{$\begin{array}{l}\text { CRO } \\
\text { C16 }\end{array}$} & \multirow{2}{*}{$\begin{array}{l}\text { CRO } \\
\text { C31 }\end{array}$} \\
\hline $\begin{array}{l}\text { Model } \\
\text { Model }\end{array}$ & $\begin{array}{l}\text { Group } \\
\text { Skupina }\end{array}$ & \begin{tabular}{|l} 
Financial \\
indicator \\
Financijski \\
pokazatelj
\end{tabular} & & & & & \\
\hline \multirow{3}{*}{$\begin{array}{l}\text { Input for } \\
\text { Model 1-5 } \\
\text { ulazi za modele } \\
\text { 1. }-5 \text {. }\end{array}$} & Assets / imovina & $\mathrm{A}$ & $2,725,001 €$ & $4,145,299 €$ & $1,453,053 €$ & $2,305,357 €$ & $2,818,543 €$ \\
\hline & Capital / kapital & $\mathrm{C}$ & $1,837,445 €$ & $3,086,710 €$ & $902,264 €$ & $1,419,960 €$ & $1,827,696 €$ \\
\hline & $\begin{array}{l}\text { Number of employees } \\
\text { broj zaposlenih }\end{array}$ & NE & 36.2 & 32.2 & 22.8 & 41.2 & 46.0 \\
\hline \multirow{3}{*}{$\begin{array}{l}\text { Output for } \\
\text { Model } 1 \\
\text { izlazi za model } 1 .\end{array}$} & \multirow{3}{*}{$\begin{array}{l}\text { Liquidity ratio } \\
\text { omjer likvidnosti }\end{array}$} & $\mathrm{CR}$ & 3.430 & 3.183 & 3.438 & 3.722 & 3.166 \\
\hline & & QR & 2.584 & 2.364 & 2.772 & 2.842 & 2.162 \\
\hline & & CashR & 1.493 & 1.273 & 1.592 & 1.772 & 1.120 \\
\hline \multirow{3}{*}{$\begin{array}{l}\text { Output for } \\
\text { Model } 2 \\
\text { izlazi za model } 2 .\end{array}$} & \multirow{3}{*}{$\begin{array}{l}\text { Profi tability ratio } \\
\text { omjer profitabilnosti }\end{array}$} & ROA & $13.3 \%$ & $8.3 \%$ & $8.4 \%$ & $16.1 \%$ & $20.1 \%$ \\
\hline & & ROE & $23.6 \%$ & $14.7 \%$ & $17.6 \%$ & $26.9 \%$ & $36.8 \%$ \\
\hline & & ROS & $8.7 \%$ & $6.1 \%$ & $6.5 \%$ & $10.3 \%$ & $11.5 \%$ \\
\hline \multirow{3}{*}{\begin{tabular}{|l|} 
Output for \\
Model 3 \\
izlazi za model 3. \\
\end{tabular}} & \multirow{3}{*}{$\begin{array}{l}\text { Activity ratio } \\
\text { omjer aktivnosti }\end{array}$} & GVA & $34,157 €$ & $47,024 €$ & $35,617 €$ & $28,826 €$ & $24,390 €$ \\
\hline & & ATR & 1.742 & 1.569 & 1.723 & 1.742 & 2.029 \\
\hline & & CAT & 3.433 & 3.433 & 3.344 & 3.404 & 3.596 \\
\hline \multirow{3}{*}{$\begin{array}{l}\text { Output for } \\
\text { Model } 4 \\
\text { izlazi za model } 4 .\end{array}$} & \multirow{3}{*}{$\begin{array}{l}\text { Efficiency ratio } \\
\text { omjer učinkovitosti }\end{array}$} & \begin{tabular}{|l|} 
EBITDA \\
\end{tabular} & $552,149 €$ & $724,127 €$ & $260,280 €$ & $520,578 €$ & $669,647 €$ \\
\hline & & $\mathrm{E}$ & 1.132 & 1.093 & 1.109 & 1.154 & 1.170 \\
\hline & & $\mathrm{AU}$ & 1.738 & 1.576 & 1.673 & 1.747 & 2.036 \\
\hline \multirow{3}{*}{$\begin{array}{l}\text { Output for } \\
\text { Model } 5 \\
\text { izlazi za model } 5 .\end{array}$} & \multirow{3}{*}{$\begin{array}{l}\text { Leverage ratio } \\
\text { omjer financijske } \\
\text { poluge }\end{array}$} & $\mathrm{D} / \mathrm{E}$ & 0.753 & 0.723 & 0.692 & 0.741 & 0.892 \\
\hline & & TDA & 0.118 & 0.124 & 0.099 & 0.116 & 0.132 \\
\hline & & TLTSF & 0.329 & 0.315 & 0.310 & 0.330 & 0.372 \\
\hline
\end{tabular}

SI - Slovenia; CRO - Croatia; C16 - Wood processing; C31 - Furniture manufacturing / SI - Slovenija; CRO - Hrvatska; C16-prerada drva; C31 - proizvodnja namještaja 
$\mathrm{p}=0.031$ ). Further, the Games-Howell post hoc test revealed that the differences between all pairs of four groups, except the pair SI-C16 and CRO-C16 for variable $\mathrm{A}$ and for all pairs of four groups for variable $\mathrm{C}$, are statistically significant. The differences between the four groups for variable NE is also statistically significant (one-way ANOVA, $\mathrm{F}(3.16)=105.669$, $\mathrm{p}<0.001)$. The Bonferroni post hoc test revealed that the differences between pairs of all groups except pair SI-C16 and CRO-C31 are statistically significant. There are no statistically significant differences between the groups of the profitability ratios ROE (oneway ANOVA, $\mathrm{F}(3.16)=1.172, \mathrm{p}=0.351$ ) and ROA (one-way ANOVA, $\mathrm{F}(3.16)=2.578, \mathrm{p}=0.090$ ), and the only statistically significant difference for variable ROS is between SI-C16 and SI-C31 (one-way ANOVA, $F(3.16)=4.182, p=0.023$, Games-Howell post hoc test $\mathrm{p}=0.024)$. However, the average values of the profitability ratios differ quite a lot, as do their variances. The differences between the four groups for variable
GVA are statistically significant (one-way ANOVA, $\mathrm{F}(3.16)=66.963, \mathrm{p}<0.001)$ as well as for variable EBITDA (one-way ANOVA, $F(3.16)=15.660$, $\mathrm{p}<0.001)$. GVA shows much higher values in SI groups that CRO groups, with the highest value for the group SI-C16. Regarding the variable EBITDA, both CRO groups have average values, while SI-C31 achieves the highest and SI-C16 the lowest values.

\subsection{Results of DEA and Malmquist Productivity Index}

3.2. Rezultati DEA analize i Malmquistova indeksa produktivnosti

The DEA efficiency analysis using the models over the years did not give any specific trend based on which it could be concluded that the efficiency is increasing or decreasing over time. By comparing the efficiency of average values using the models (Figure 1), it can be concluded that for all of them the most effective clusters are SI-C16-larger, CRO-C16-micro and CRO-C31-micro, while the worst efficiency is

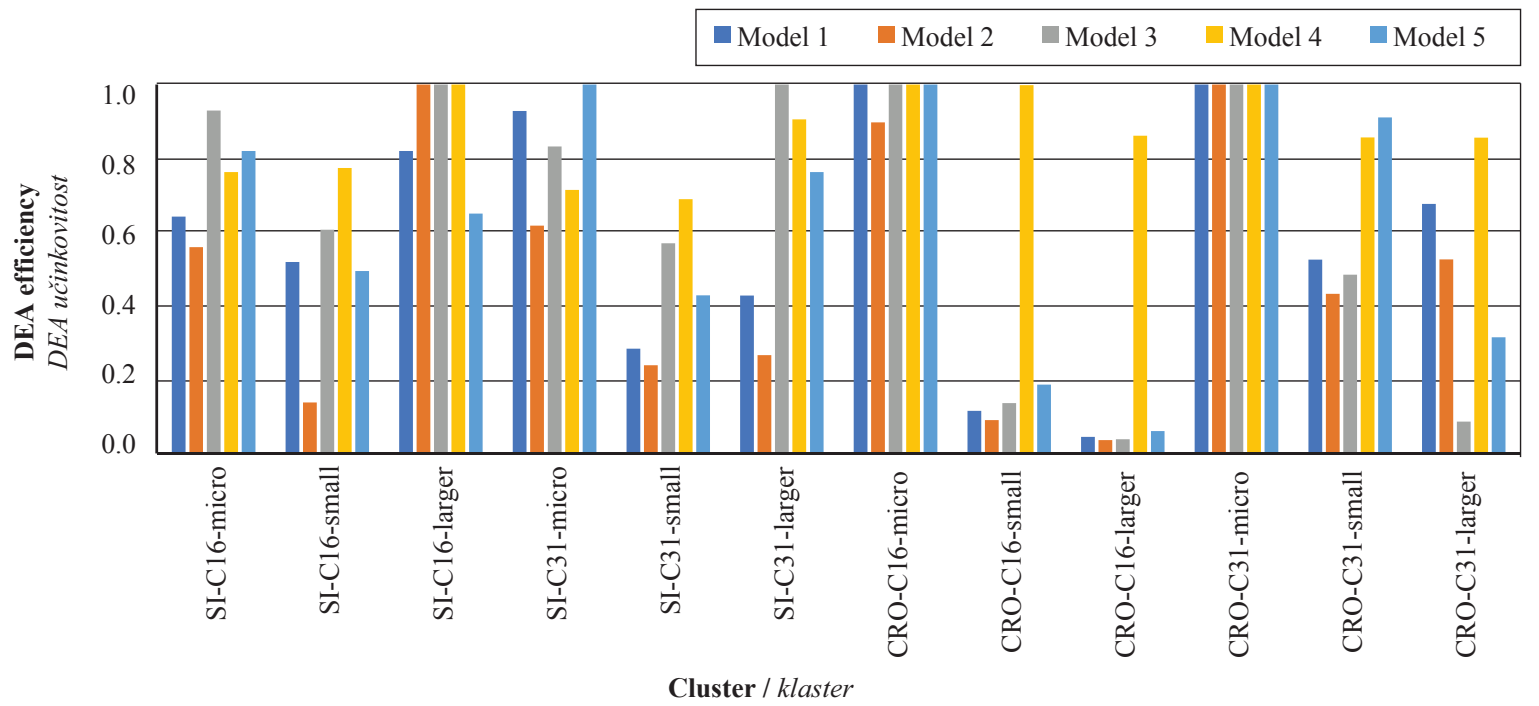

Figure 1 DEA efficiency analysis - average by years of Models 1-5

Slika 1. Analiza učinkovitosti DEA - prosjek po godinama za modele 1. - 5.

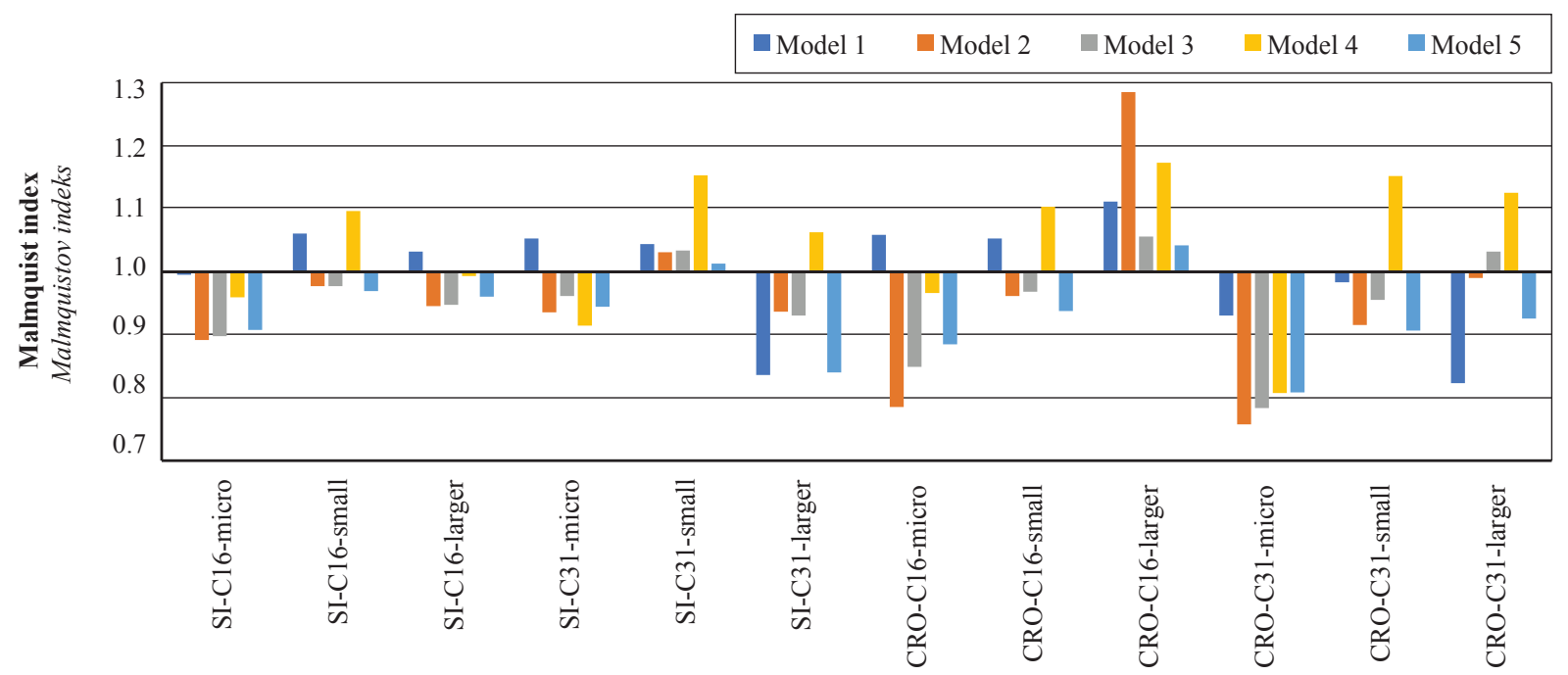

Cluster / klaster

Figure 2 Malmquist Index - average by year of models 1-5

Slika 2. Malmquistov indeks - prosječne vrijednosti po godinama za modele 1. - 5. 
Table 6 DEA/MI weighted score of all models and ranking of clusters

Tablica 6. DEA/MI ponderirana ocjena svih modela i rangiranje klastera

\begin{tabular}{|l|c|c|c|c|c|c|c|}
\hline \multirow{2}{*}{ DMU } & \multicolumn{5}{c|}{ Weighted Score / Ponderirana vrijednost } & \multicolumn{2}{c|}{$\begin{array}{c}\text { Average of Models 1-5 } \\
\text { Posječne vrijednosti modela 1. - 5. }\end{array}$} \\
\cline { 2 - 8 } & Model 1 & Model 2 & Model 3 & Model 4 & Model 5 & $\begin{array}{c}\text { Weighted score } \\
\text { Ponderirana vrijednost }\end{array}$ & $\begin{array}{c}\text { Ranking } \\
\text { Rangiranje }\end{array}$ \\
\hline CRO-C31-micro & 0.967 & 0.910 & 0.893 & 0.900 & 0.957 & 0.925 & 1 \\
\hline CRO-C16-micro & 0.984 & 0.802 & 0.924 & 0.941 & 0.949 & 0.920 & 2 \\
\hline SI-C16-larger & 0.856 & 0.911 & 0.966 & 0.949 & 0.741 & 0.884 & 3 \\
\hline SI-C31-micro & 0.935 & 0.654 & 0.858 & 0.736 & 0.969 & 0.830 & 4 \\
\hline SI-C16-micro & 0.726 & 0.604 & 0.903 & 0.781 & 0.837 & 0.770 & 5 \\
\hline CRO-C31-small & 0.668 & 0.584 & 0.599 & 0.904 & 0.934 & 0.738 & 6 \\
\hline SI-C31-larger & 0.536 & 0.420 & 0.949 & 0.906 & 0.777 & 0.718 & 7 \\
\hline CRO-C31-larger & 0.717 & 0.670 & 0.356 & 0.904 & 0.543 & 0.638 & 8 \\
\hline SI-C16-small & 0.664 & 0.345 & 0.713 & 0.827 & 0.640 & 0.638 & 10 \\
\hline SI-C31-small & 0.502 & 0.427 & 0.706 & 0.787 & 0.610 & 0.606 & 11 \\
\hline CRO-C16-small & 0.393 & 0.309 & 0.385 & 0.979 & 0.424 & 0.498 & 12 \\
\hline CRO-C16-larger & 0.363 & 0.358 & 0.331 & 0.907 & 0.374 & 0.467 & \\
\hline
\end{tabular}

DMU - decision-making units / DMU-donošenje odluka u jedinicama

found in CRO-C16- small and CRO-C16-larger, where, except for model 4 (efficiency ratios), the DEA values are very low. For model 4, the differences between the DMUs are the smallest and the average values are the highest.

The Malmquist productivity index (MI) average by year (Figure 2) shows the highest MI values on average for Model 4. This means that variables EBITDA, $\mathrm{E}$ and AU have improved over the years in all models. On the other hand, there is an interesting situation: the MI values are the lowest in CRO-C31-micro, a little higher, but still very low in CRO-C16-micro and SI-C16-larger, although these clusters reached the highest values of DEA efficiency index. This means that these classes have high efficiency and at the same time low total productivity in converting inputs into outputs in practically all models. The reason for this is that MI values are directly influenced by the actual values of inputs and outputs. The best in this regard are CRO-C16-larger and SI-C31-small, while the others have an average efficiency of about 1 .
To determine the most efficient cluster, we used the ranking of clusters according to both indexes (Table 6). We calculated the DEA/MI score for each model as the weighted sum of average efficiency and the normalized average of MI (5). Based on the assumption that the contribution of the annual efficiency is greater than the contribution of efficiency improvement over time (Zadnik Stirn et al., 2015), we set the weights $w_{1}=0.667$ and $w_{2}=0.333$ in DEA/MI (5) calculation. For final ranking the DEA/MI results of the Models 1-5 were aggregated by eq. (6). We assumed that all five models are equally important and set the weights $u_{1}=u_{2}=u_{3}=u_{4}=u_{5}=0.2$.

It was established that the ranking of DMUs depends also on the subjective selection of weights of importance $w_{1}$ and $w_{2}$ in eq. (5). The sensitivity analysis showed that the final ranking of DMUs remains unchanged if $w_{1}$ remains on the interval [0.547, 0.669] and consequently $w_{2}$ on the interval $[0.331,0.453]$.

If we assume that the relative efficiency is slightly to moderately more important than efficiency im-

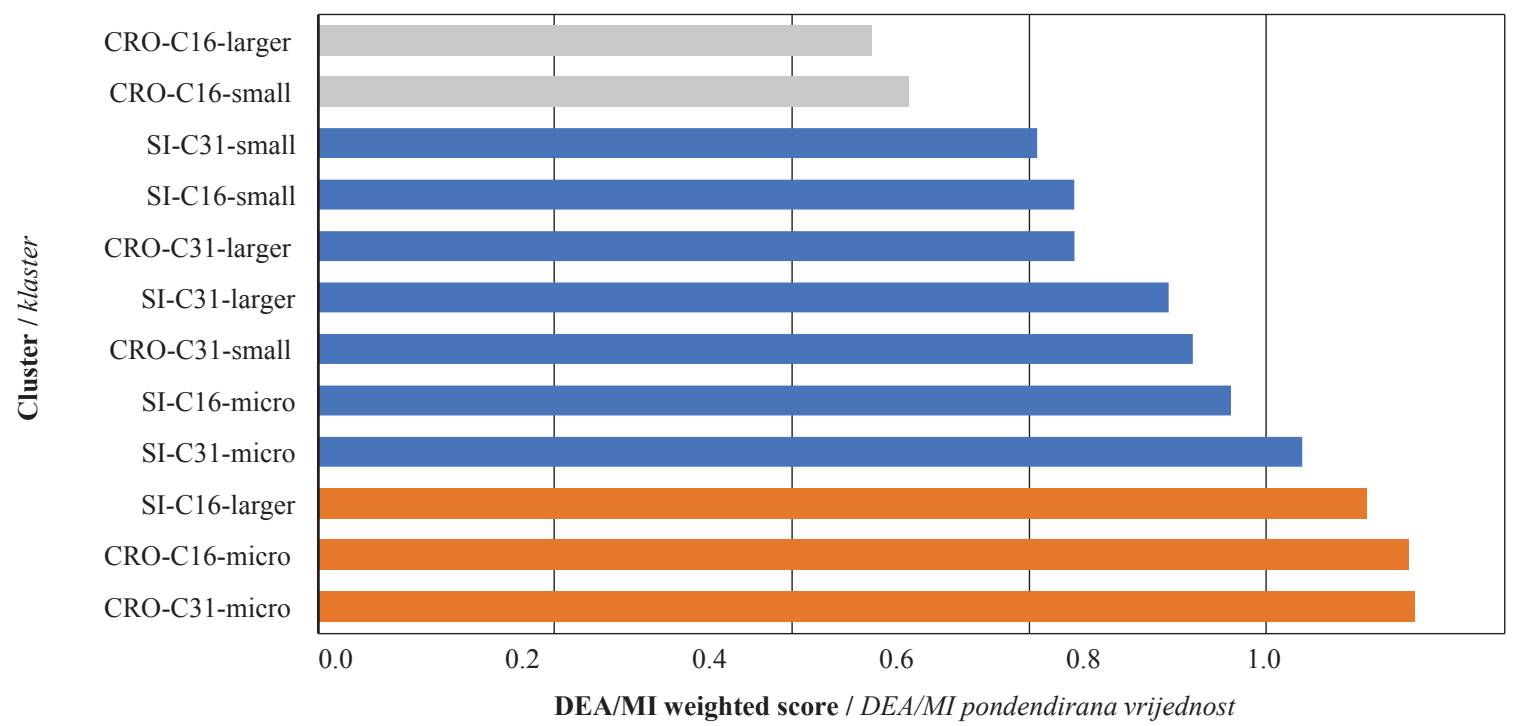

Figure 3 DEA/MI weighted score - average of models 1-5

Slika 3. DEA/MI ponderirana ocjena - prosjek modela 1. -5 . 
provement over time, then this assumption is covered by the received interval. We can conclude that the DMUs' final ranking is robust.

Regarding the DEA/MI weighted score of all models, the most effective clusters are CRO-C31-micro, CRO-C16-micro and SI-C16-larger (Figure 3). On the other hand, CRO-C16-small and CRO-C16-larger have the worst results. It can also be concluded that the CRO-C31-micro cluster is quite balanced, with high values of the DEA/MI index in all models, but not the highest relative values in any model regarding the other clusters (Table 6). In the CRO-C16-micro and SI-C16-larger clusters, in contrast to the aforementioned CRO-C31-micro cluster, there are bigger differences between the values of the DEA/MI index among the models: CRO-C16-micro has the highest relative value in model 1 , which demonstrates its effectiveness in liquidity ratios, but it is relatively low in profitability ratios, while the SI-C16-larger is the best in activity ratios, and much worse with leverage ratios. The final results are very similar to the DEA values that were highest in these clusters.

Clusters CRO-C31-micro and CRO-C16-micro are undoubtedly the most effective, both with DEA/MI weighted scores over 0.9 , and cluster SI-C16-larger with an overall score just a bit below 0.9. A more detailed view of the average values of the variables/indicators in these clusters shows that the CRO-C31-micro cluster achieved exceptionally high values in all activity ratios and variable $\mathrm{E}$, these values being the highest among all clusters. In CRO-C16-micro, very high values (above average) were recorded both in activity ratios and liquidity ratios and in variable E. For the cluster SI-C16-larger, a very high value can be observed in the GVA indicator, while the other values are slightly above average. For clusters CRO-C16-small and CRO-C16-larger, however, slightly under-average values were observed in all indicators and very low values for GVA and QR. Consequently, it can be concluded that the efficiency of a cluster is also strongly related to the average values of indicators: the higher these values, the more effective the cluster.

Clusters can also be grouped into four major groups (by country and subsector), as we did in calculating the average values of indicators in Chapter 3.1, where the differences are statistically significant for the majority of the indicators, except profitability ratios, where no statistically significant differences between the groups was established. We also established that the SI-C16 deviates in particular in values A, C, EBITDA and GVA, while the HR-C31 is the best in activity ratios (ROA, ROE and ROS) and NE. A similar distribution is obtained if the average of the DEA/ MI weighted score of efficiency for these groups is calculated. The SI-C16 and CRO-C31 groups achieve above average overall efficiency and, however, the values are almost identical (SI-C16 with a value of 0.764 and CRO-C31 with a value of 0.767 ). Regarding this group, SI-C31 reached the value of 0.718 , and CRO-C16 group achieved the worst average efficiency (0.628). It can be concluded that the performance of the group is also greatly influenced by the average values of individual indicators for the last year (i.e., 2017). Similar results were obtained for the wood industry in Slovenia (Kropivšek and Grošelj, 2019). Interestingly, CRO-C16 achieved a very poor performance, and this may be a consequence of various factors, such as the lower degree of technological development and less use of innovative solutions that generate higher added value in production, as well as the long-term stability of domestic production in the supply of wood raw material from state forests in Croatia and the stability of wood assortments prices (MPS, 2017).

\section{CONCLUSIONS}

\section{ZAKLJUČAK}

The wood industry, as a traditional sector, represents a very important part of the economy in terms of ensuring a sustainable development of society and transition to a low-carbon society in both studied countries, Slovenia and Croatia. In recent years, the wood industry in Slovenia has undergone a great deal of improvement: many new investments have been made, a lot has been invested in the promotion of wood, especially wooden construction, practically all financial indicators have improved, exports have increased and many macroeconomic and political measures for its improvement have been undertaken (Kropivšek et al., 2017). Similarly, Croatia has also taken many steps to improve its wood industry (CWC, 2019). For instance, the Croatian government has recognized the woodprocessing industry as one of its strategic priorities, and used financial instruments to support development of wood processing and furniture production in accordance with the principles and policies of a sustainable economy and rural development (MPS, 2017).

To ensure the development of the wood sector, it is crucial to know its current status, and one way to achieve this is through an international comparative evaluation of its operational efficiency, based on financial data and/or indicators. For the evaluation carried out in the present study, we used Data Envelopment Analysis (DEA), the Malmquist Productivity Index (MI) and DEA/MI weighted score, which has been rarely used before for the evaluation of operational efficiency of wood sector, especially not for the comparison between different countries. The research covered the most successful companies in the wood industry sectors (C16 and C31) in Slovenia and Croatia with the highest credit appraisal rating in 2017 and with more than five employees, divided into 12 clusters regarding the size of a company. We studied the effectiveness of the clusters for the period 2013-2017.

The descriptive statistics of the inputs and outputs of models 1-5 for the year 2017 show that all the observed companies are excellent, especially in terms of their solvency (liquidity) and profitability ratios, with a very low share of debt. Analysing the four groups (C16 and C31 sectors in both Slovenia and Croatia) the differences are statistically significant for the 
majority of the indicators, except for the profitability ratios, where no statistically significant differences between the groups were established.

Regarding the DEA/MI weighted score of all models (Models 1-5), the most effective clusters are CRO-C31-micro, CRO-C16-micro and SI-C16-larger, while CRO-C16-small and CRO-C16-larger have the worst results. Those clusters are most effective (with the highest DEA values), but have low total productivity (low MI values). The average values of the indicators in these groups are also above average, especially in activity ratios, liquidity ratios, indicator $\mathrm{E}$ and/or GVA. Consequently, it can be concluded that the efficiency of the cluster is also strongly correlated with the average values of the indicators. In general, within grouped clusters regarding country and subsector, groups SI-C16 and CRO-C31 achieve the highest average values for the weighted score of efficiency, while CRO-C16 has the lowest values.

Important potential limitations of this study are the sample size, where only $3.1 \%$ of the related firms in Slovenia and $4.0 \%$ in Croatia were analysed, and a short period of observation. However, the results are still meaningful as they cover the best and largest companies (those with more than five employees and rated $\mathrm{A}$ in credit appraisal), and give a more comparable picture between the countries and industries with all input data from business reports. As an extension of this study, it may be of interest to observe all the companies in the related sectors to get a more complete picture. It would also be very interesting to expand the sample to more countries and use a longer observation period.

\section{Acknowledgements - Zahvala}

The authors acknowledge the financial support this study received from the Slovenian Research Agency (research core funding No. P4-0015 and P4-0059).

\section{REFERENCES}

\section{LITERATURA}

1. Ablanedo-Rosas, J. H.; Gao, H.; Zheng, X.; Alidaee, B.; Wang, H., 2010: A study of the relative efficiency of Chinese ports: a financial ratio-based data envelopment analysis approach. Expert Systems, 27: 349-362. http://dx. doi.org/10.1111/j.1468-0394.2010.00552.x.

2. Banker, R. D.; Charnes, A.; Cooper, W. W., 1984: Some Models for Estimating Technical and Scale Inefficiencies in Data Envelopment Analysis. Management Science, 30: 1078-1092.

http://dx.doi.org/10.1287/mnsc.30.9.1078.

3. Braunsberger, F.; Hlavaty, M.; Schlamberger, N.; Stevanovič, S., 2010: Standardna klasifikacija dejavnosti 2008. Ljubljana: Statistični urad Republike Slovenije.

4. Bui, Y. H.; Sarath, D.; Ahmed, A. D., 2016: Efficiency of Australian superannuation funds: a comparative assessment. Journal of Economic Studies, 43: 1022-1038. http://dx.doi.org/10.1108/JES-05-2015-0088.

5. Charnes, A.; Cooper, W. W.; Rhodes, E., 1978: Measuring the efficiency of decision making units. European Journal of Operational Research, 2: 429-444. http://dx.doi.org/10.1016/0377-2217(78)90138-8.
6. Cook, W. D.; Seiford, L. M., 2009: Data envelopment analysis (DEA) - Thirty years on. European Journal of Operational Research, 192: 1-17. http://dx.doi.org/10.1016/j.ejor.2008.01.032.

7. Cooper, W. W.; Seiford, L. M.; Tone, K., 2006: Introduction to Data Envelopment Analysis and Its Uses: With DEA-Solver Software and References. Springer US.

8. Delen, D.; Kuzey, C.; Uyar, A., 2013: Measuring firm performance using financial ratios: A decision tree approach. Expert Systems with Applications, 40: 39703983. http://dx.doi.org/10.1016/j.eswa.2013.01.012.

9. Diaz-Balteiro, L.; Casimiro Herruzo, A.; Martinez, M.; González-Pachón, J., 2006: An analysis of productive efficiency and innovation activity using DEA: An application to Spain's wood-based industry. Forest Policy and Economics, Innovation and entrepreneurship in the forest sector, 8: 762-773.

http://dx.doi.org/10.1016/j.forpol.2005.06.004.

10. Färe, R.; Grosskopf, S.; Norris, M.; Zhang, Z., 1994: Productivity Growth, Technical Progress, and Efficiency Change in Industrialized Countries. The American Economic Review, 84: 66-83.

11. Fenyves, V.; Tarnóczi, T.; Zsidó, K., 2015: Financial Performance Evaluation of Agricultural Enterprises with DEA Method. Procedia Economics and Finance, Emerging Markets Queries in Finance and Business 2014, EMQFB 2014, 24-25 October 2014, Bucharest, Romania 32: 423-431 http://dx.doi.org/10.1016/S2212-5671(15)01413-6.

12. Fernández, D.; Pozo, C.; Folgado, R.; Jiménez, L.; Guillén-Gosálbez, G., 2018: Productivity and energy efficiency assessment of existing industrial gases facilities via data envelopment analysis and the Malmquist index. Applied Energy, 212: 1563-1577. http://dx.doi.org/10.1016/j.apenergy.2017.12.008.

13. Friedlob, G. T.; Schleifer, L. L. F., 2003: Essentials of Financial Analysis. John Wiley \& Sons.

14. Gitman, L. J., 2003: Principles of Managerial Finance. Person.

15. Gombola, M. J.; Ketz, J. E., 1983: Financial Ratio Patterns in Retail and Manufacturing Organizations. Financial Management, 12: 45-56. http://dx.doi.org/10.2307/3665210.

16. Hadad, Y.; Keren, B.; Hanani, M. Z., 2015: Combining data envelopment analysis and Malmquist Index for evaluating police station efficiency and effectiveness. Police Practice and Research, 16: 5-21. http://dx.doi.org/10.1080/15614263.2013.845945.

17. Halkos, G. E.; Tzeremes, N. G., 2012a: Industry performance evaluation with the use of financial ratios: An application of bootstrapped DEA. Expert Systems with Applications, 39: 5872-5880. http://dx.doi.org/10.1016/j.eswa.2011.11.080.

18. Halkos, G. E.; Tzeremes, N. G., 2012b: Analyzing the Greek renewable energy sector: A Data Envelopment Analysis approach. Renewable \& Sustainable Energy Reviews, 16: 2884-2893. http://dx.doi.org/10.1016/j.rser.2012.02.003.

19. Helfert, E. A., 2001: Financial Analysis Tools and Techniques: A Guide for Managers. McGraw-Hill Education.

20. Hemmasi, A.; Talaeipour, M.; Khademi-Eslam, H.; Farzipoor Sean, R.; Pourmousa S., H., 2011: Using DEA window analysis for performance evaluation of Iranian wood panels industry. African Journal of Agricultural Research, 6: 1802-1806.

http://dx.doi.org/10.5897/AJAR10.733. 
21. Hollingsworth, B.; Smith, P., 2003: Use of ratios in data envelopment analysis. Applied Economics Letters, 10: 733-735. http://dx.doi.org/10.1080/1350485032000133381.

22. Johnes, J.; Izzeldin, M.; Pappas, V., 2009: Efficiency in Islamic and conventional banks: A comparison based on financial ratios and data envelopment analysis. Lancaster: Economics Working Paper Series. The Economics Department, Lancaster University.

23. Klarić, K.; Greger, K.; Klarić, M.; Andrić, T.; Hitka, M.; Kropivšek, J., 2016: An Exploratory Assessment of FSC Chain of Custody Certifi cation Benefi ts in Croatian Wood Industry. Drvna industrija, 67 (3): 241-248.

24. Kropivšek, J.; Grošelj, P., 2019: Long-term Financial Analysis of the Slovenian Wood Industry Using DEA. Drvna industrija, 70 (1): 61-70. http://dx.doi.org/10.5552/drvind.2019.1810.

25. Kropivšek, J.; Grošelj, P.; Likar, B.; Jošt, M., 2011: Economics of Slovenian wood-industry. Presented at the Development trends in economics and management in wood processing and furniture manufacturing. Kozina, Slovenia: WoodEMA, i.a, pp. 91-96.

26. Kropivšek, J.; Jošt, M., 2013: Financial analysis of Slovenian wood industry. In: Markets for wood and wooden products. Jelačić, D. (ed.), WoodEMA, i.a., Zagreb, Croatia, pp. 57-74.

27. Kropivšek, J.; Milavec, I.; Likar, B., 2017: Analiza poslovanja slovenske lesne panoge: Les/Wood, 66: 47-56. http://dx.doi.org/10.26614/les-wood.2017.v66n02a05.

28. Li, H.; Wu, L., 2016: Analysis of financial support efficiency for China's wind power industry. Energy Sources, part B: Economics, Planning, and Policy, 11: 1035-1041. http://dx.doi.org/10.1080/15567249.2016.1185480.

29. Liu, F.-H. F.; Wang, P., 2008: DEA Malmquist productivity measure: Taiwanese semiconductor companies. International Journal of Production Economics, Special Section on Recent Developments in the Design, Control, Planning and Scheduling of Productive Systems, 112: 367-379. http://dx.doi.org/10.1016/j.ijpe.2007.03.015.

30. Nikoomaram, H.; Mohammadi, M.; Mahmoodi, M. R., 2010: Efficiency Measurement of Enterprises Using the Financial Variables of Performance Assessment and Data Envelopment Analysis. Applied Mathematical Sciences, 4: 1843-1854.

31. Oberholzer, M.; Westhuizen, G. V. der, 2004: An empirical study on measuring efficiency and profitability of bank regions. Meditari: Research Journal of the School of Accounting Sciences, 12: 165-178.

32. Örkcü, H. H.; Balıkçı, C.; Dogan, M. I.; Genç, A., 2016: An evaluation of the operational efficiency of turkish airports using data envelopment analysis and the Malmquist productivity index: 2009 - 2014 case. Transport Policy, 48: 92-104. http://dx.doi.org/10.1016/j.tranpol.2016.02.008.

33. Palepu, K. G.; Healy, P. M.; Bernard, V. L., 2003: Business Analysis and Valuation Using Financial Statements: Text and Cases, $3^{\text {rd }}$ ed. ed. Manson, Ohio: Thomson South-Western.

34. Pastor, J. T.; Ruiz, J. L., 2007: Variables With Negative Values In Dea. In: Zhu, J., Cook, W. D. (eds.), Modeling Data Irregularities and Structural Complexities in Data Envelopment Analysis. Boston, MA: Springer US, pp. 63-84. http://dx.doi.org/10.1007/978-0-387-71607-7_4.

35. Perić, I.; Grladinović, T.; Greger, K.; Jože, K., 2015: Sources of Competitiveness for Furniture Manufacturing Firms: A Review of Literature and Research Issues. In: Proceeding of the $26^{\text {th }}$ International Conference on Wood Modification and Technology: Implementation of wood science in woodworking sector. Grbac, I. (ed.), Faculty of Forestry, University of Zagreb, Zagreb, Croatia, pp. 179-185.

36. Perić, I.; Grošelj, P.; Sujova, A.; Kalem, M.; Greger, K.; Kropivšek, J., 2019: Analysis of Implementation of Integrated Information Systems in Croatian Wood Processing Industry. Drvna industrija, 70 (2): 129-139.

https://doi.org/10.5552/drvind.2019.1911.

37. Peterson-Drake, P.; Fabozzi, F. J., 2010: The Basics of Finance: An Introduction to Financial Markets, Business Finance, and Portfolio Management. John Wiley \& Sons.

38. Pirc Barčić, A.; Liker, B.; Motik, D.; Moro, M., 2015: Financial Analysis of Croatian Furniture Industry. In: Proceeding of the $26^{\text {th }}$ International Conference on Wood Modification and Technology: Implementation of wood science in woodworking sector. Grbac, I. (ed.), Faculty of Forestry, University of Zagreb, Zagreb, Croatia, pp. 187191.

39. Potkány, M.; Giertl, G., 2014: Comparison of selected performance indicators of woodworking industry in the Czech Republic and Slovakia. Presented at the Position and role of the forest based sector in the green economy, Zvolen, Slovakia: WoodEMA, i.a, pp. 131-138.

40. Salehirad, N.; Sowlati, T., 2006: Productivity and efficiency assessment of the wood industry: A review with a focus on Canada. Forest Products Journal 56.

41. Salehirad, N.; Sowlati, T., 2007: Dynamic efficiency analysis of primary wood producers in British Columbia. Mathematical and Computer Modelling, 45: 1179-1188. http://dx.doi.org/10.1016/j.mcm.2006.10.003.

42. Sayari, N.; Simga-Mugan, C., 2017: Industry specific financial distress modeling. BRQ Business Research Quarterly, 20: 45-62. http://dx.doi.org/10.1016/j.brq.2016.03.003.

43. Seiford, L. M.; Zhu, J., 2002: Modeling undesirable factors in efficiency evaluation. European Journal of Operational Research, 142: 16-20. http://dx.doi.org/10.1016/S0377-2217(01)00293-4.

44. Šooš, T.; Lautar, K.; Urbančič, H.; Kobe Logonder, N.; Kmet Zupančič, R.; Fajić, L.; Čokl, A.; Gantar, J.; Lenarčič, M.; Culpa, N., 2017: Strategija razvoja Slovenije 2030. Ljubljana: Služba Vlade Republike Slovenije za razvoj in evropsko kohezijsko politiko.

45. Sowlati, T.; Vahid, S., 2006: Malmquist productivity index of the manufacturing sector in Canada from 1994 to 2002 , with a focus on the wood manufacturing sector. Scandinavian journal of forest research, 21: 424-433. http://dx.doi.org/10.1080/02827580600917304.

46. Sueyoshi, T.; Goto, M., 2013: A use of DEA-DA to measure importance of R\&D expenditure in Japanese information technology industry. Decision Support Systems, 54:941-952.http://dx.doi.org/10.1016/j.dss.2012.09.017.

47. Tratnik, M.; Zager, M.; Zupanec, J., 2001: Key factors of (non)competitiveness of Slovene wood industry. In: Ways for improving woodworking industry for transitional economics: proceedings. Preddvor, Slovenia: International Symposium, pp. 107-114.

48. Vance, D. E., 2003: Financial Analysis and Decision Making: Tools and Techniques to Solve Financial Problems and Make Effective Business Decisions. New York: McGraw-Hill.

49. Zadnik Stirn, L.; Leban, V.; Grošelj, P.; Krč, J.; Pezdevšek Malovrh, S., 2015: Public forest service in Slovenia over last decade - efficiency assessment. In: Proceedings of Extended Abstracts. Presented at the International IUFRO Symposium Cross-sectoral policy impacts on managerial economics and accounting in forestry, Sarajevo, pp. 25-30. 
50. ***Ajpes JOLP, 2019: Public posting of annual reports [online]. https://www.ajpes.si/jolp (Accessed Mar. 1, 2019).

51. ***Analitika GZS, 2019: Analitika GZS [online]. https://analitika.gzs.si/ (Accessed Feb. 4, 2019).

52. ***Bisnode, 2019: Bonitete.Si - bonitetne informacije podjetij. https://bonitete.bisnode.si (Accessed Mar. 1, 2019).

53. ${ }^{* * *}$ CBS, 2019: Croatian Bureau of Statistics - Republic of Croatia. https://www.dzs.hr/default_e.htm (Accessed Apr. 8, 2019).

54. ***CWC, 2019: Croatian Wood Cluster. http://www.drvniklaster.hr/ (Accessed May. 6, 2019).

55. ***MPS, 2017: Odluka o donošenju Strategije razvoja prerade drva i proizvodnje namještaja Republike Hrvatske 2017. - 2020. s Akcijskim planom provedbe 2017. - 2020. https://narodne-novine.nn.hr/clanci/sluzbeni/2017_05_44_1001.html (Accessed Mar. 10, 2017).

56. ${ }^{* * * N A C E}, 2019$ : Glossary:Statistical classification of economic activities in the European Community (NACE)
- Statistics Explained. https://ec.europa.eu/eurostat/statistics-explained/index.php/Glossary:Statistical_classification of economic activities in the European Community_(NACE) (Accessed Feb. 10, 2019).

57. ***ZGD-1-UPB3, 2009: Zakon o gospodarskih družbah. https://www.uradni-list.si/glasilo-uradni-list-rs/ vsebina/2009-01-3036?sop=2009-01-3036 (Accessed Feb. 4, 2019).

\section{Corresponding address:}

IVANA PERIĆ, Ph.D.

University of Zagreb

Faculty of Forestry

Wood Technology Department

Svetošimunska 25, 10000 Zagreb, CROATIA

e-mail: iperic@sumfak.hr 